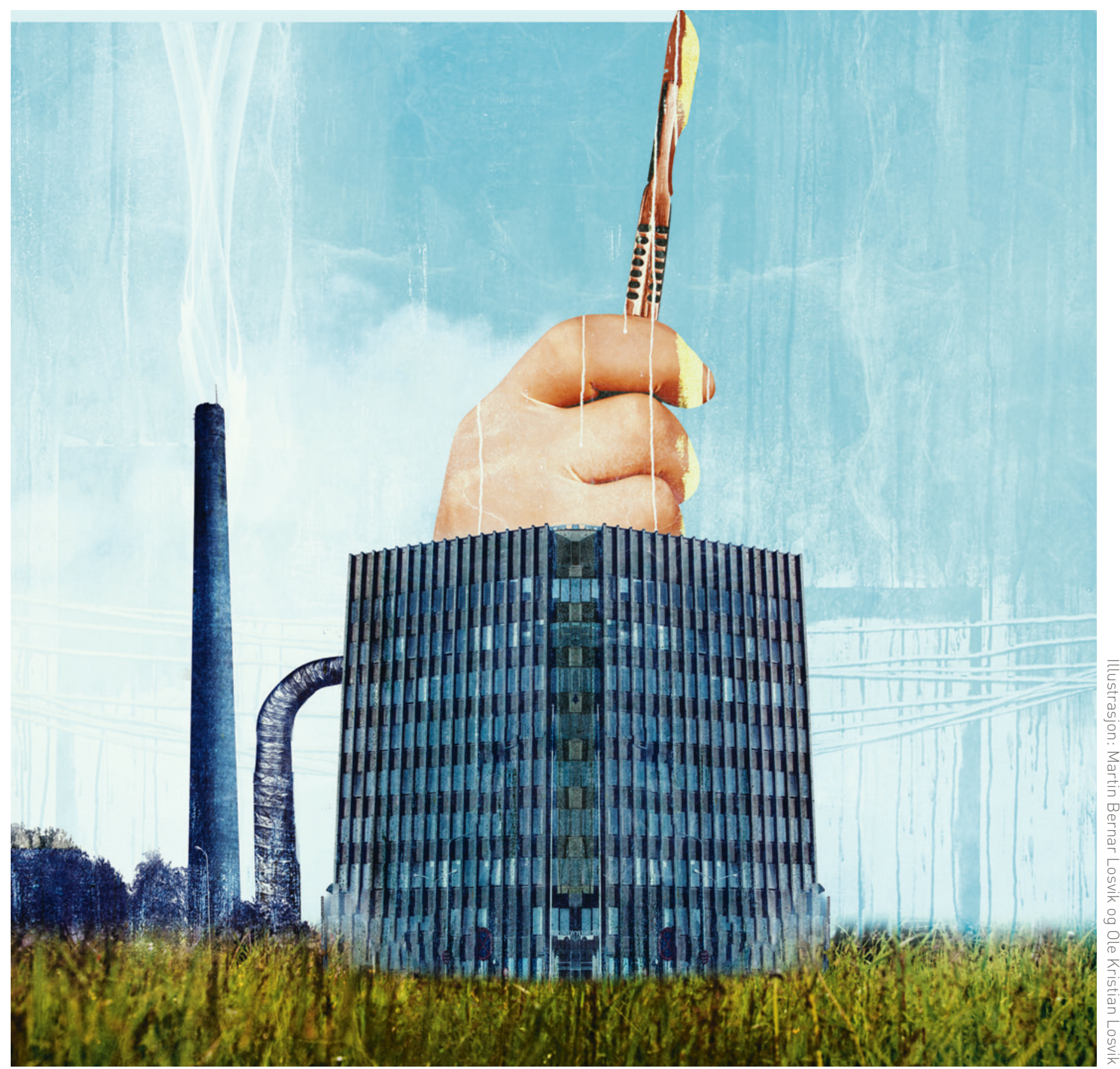

\title{
Nordlandssykehuset Bodø
}

\footnotetext{
(2)Det somatiske sykehuset i Bodø ble tatt i bruk i 1927 og hadde da bare fire leger. Den karakteristiske nordblokken, vist på bildet, sto ferdig i 1972 etter nesten 20 års diskusjon og planlegging. Det nye sykehuset i Bodø bygges nå med en kombinasjon av nye bygg og modernisering av den gamle bygningsmassen. 